\title{
Orthoptera species checklist of Bukit Timah Nature Reserve in the Zoological Reference Collection, Singapore
}

\author{
M.K. Tan \\ Department of Biological Sciences, National University of Singapore, \\ 14 Science Drive 4, 117543 Singapore \\ orthoptera.mingkai@gmail.com
}

\begin{abstract}
While work on Orthoptera in Singapore is not lacking, there is no species checklist for the species found within the Bukit Timah Nature Reserve (BTNR). Here, a checklist of orthopterans in the reserve is given based on specimens deposited in the Zoological Reference Collection of the Lee Kong Chian Natural History Museum, Singapore. In total, 83 species, 30 from the suborder Caelifera (grasshoppers and relatives) and 53 from the suborder Ensifera (crickets, katydids, and relatives), are recorded from the reserve.
\end{abstract}

Keywords. Crickets, diversity, grasshoppers, insects, katydids, richness

\section{Introduction}

There are more than 2000 species of grasshoppers, crickets, and katydids in Southeast Asia (Cigliano et al., 2018; Tan et al., 2017c). Collectively known as the Orthoptera, the grasshoppers belong to the monophyletic suborder Caelifera, whereas the crickets and katydids belong to the other monophyletic suborder Ensifera (Song et al., 2015). These insects include a very few species that are notorious pests (Willemse, 2001). However, owing to the richness in species and diversity of form, orthopterans provide more ecosystem services than might have been expected. They can function as potentially mutualistic pollinators (e.g., Tan \& Tan, 2018), predators of other pest species, prey to charismatic species (e.g., Fung et al., 2018) and potential ecological indicators (e.g., Tan et al., 2017a). Because many species are found only in forests, and are cryptic and active at night, they are poorly known and draw little attention and appreciation from the public. These points hold true for species throughout Southeast Asia, including Singapore.

Nonetheless, Orthoptera are relatively well studied in Singapore, with numerous local checklists (e.g., Tan, 2010, 2011, 2012a, 2012b, 2014; Tan \& Wang, 2012; Tan et al., 2012). Species new to science have also been discovered as recently as 2017 (e.g., Tan, 2017).

The comprehensive biodiversity survey of the 163 ha Bukit Timah Nature Reserve (BTNR) has been introduced by Chan \& Davison (2019). Although there are combined species checklists for the two main forested nature reserves in Singapore considered together (namely BTNR and the Central Catchment Nature Reserve [CCNR] (Tan, 2012a, 2012b, 2017), a list exclusive to BTNR has not been 
available. Moreover, the published checklists were based only on recent collections in the 2010s. Older specimens collected and deposited in the Lee Kong Chian Natural History Museum since the 1960s were not included. These factors suggest the need for a species checklist exclusive to BTNR based on collections since the 1960s. Therefore, making use of specimens deposited in the Zoological Reference Collection (ZRC), Lee Kong Chian Natural History Museum (LKCNHM), a species checklist of Orthoptera from BTNR is presented here. This checklist provides baseline information for future work on orthopterans and insects in BTNR, as well as providing information for conservation management.

\section{Materials and Methods}

Specimens deposited in the ZRC were examined between 2014 and 2015 and identified to at least genus level based on species descriptions, taxonomic keys, and expert opinion (see details in Tan 2012a, 2012b, 2017). Only specimens definitely collected from within BTNR were used to compile the species checklist.

\section{Results}

In total, 196 specimens were examined and identified to at least genus level from the ZRC. They represent 83 species, of which 30 are from the suborder Caelifera (grasshoppers and relatives) and 53 from the suborder Ensifera (crickets, katydids, and relatives). Species in BTNR represent nine of the 16 monophyletic lineages in the orthopteran phylogeny (sensu Song et al., 2015). All species recorded are listed in Table 1. Specimens examined were mainly collected in three time-periods: (i) 1960s to late 1970 s by D. H. Murphy (105 specimens, 34 species), (ii) 1980s by H. K. Lua (33 specimens, 24 species), and (iii) early 2010 s by M. K. Tan ( 58 specimens, 42 species) (Table 1).

\section{Discussion}

According to Tan (2012a, 2017), as many as 156 species of Orthoptera have been recorded in BTNR and CCNR considered as a whole. Here, 83 species from BTNR represent slightly more than $50 \%$ of the known species from both nature reserves. This is surprising since the CCNR (2,600 ha) is much larger in area than BTNR (163 ha). The CCNR also includes a greater variety of habitats, including the Nee Soon freshwater swamp forest, which probably also contributes to the larger species pool in the CCNR, owing to the presence of species more specialised to the swamp forest habitat.

The orthopteran species collected over the three time-periods are different. Some species were only recorded in recent surveys (early 2010s), and others have not 
Table 1. Species checklist of Orthoptera in Bukit Timah Nature Reserve, Singapore, based on specimens in the Zoological Reference Collection (ZRC) of the Lee Kong Chian Natural History Museum (LKCNHM). The species are listed by the suborders and then alphabetically at family (subfamily) and taxon levels.

\begin{tabular}{|c|c|c|c|c|}
\hline Family (Subfamily) & Taxon & $\begin{array}{l}\text { 1960s to } \\
1970 s\end{array}$ & 1980s & $2010 s$ \\
\hline
\end{tabular}

\section{Suborder Caelifera}

\section{Acrididae}

Acridinae

Acrida willemsei

Phlaeoba infumata

Catantopinae

Apalacris varicornis

Lucretilis sp. (Fig. 1A)

Sedulia specularia

Stenocatantops splendens

Traulia azureipennis

Xenocatantops humilis

Cyrtacanthacridinae

Valanga nigricornis

Oedipodinae

Aiolopus thalassinus tamulus

Pternoscirta caliginosa

Trilophidia annulata

Oxyinae

Oxya japonica japonica

Pseudoxya diminuta

\section{Chorotypidae}

Chorotypinae

Erianthinae

Chorotypus biemarginatus (Fig. 1B)

Erianthus sp.

\section{Pyrgomorphidae}

Pyrgomorphinae

Atractomorpha sp.

Tagasta marginella

\section{Tetrigidae}

Batrachideinae

Cladonotinae

Discotettiginae

Metrodorinae

Scelimeninae

Saussurella sp.
Potua coronata
Phaesticus mellerborgi
Mazarredia sp.
Falconius bedoti
Loxilobus sp.
Scelimena producta

$+$

$+$

$+$

$+$

$+$ 
Table 1. Continuation.

\begin{tabular}{|c|c|c|c|c|}
\hline Family (Subfamily) & Taxon & 1960 s to $1970 \mathrm{~s}$ & $1980 \mathrm{~s}$ & 2010s \\
\hline \multirow[t]{4}{*}{ Tetriginae } & Coptotettix sp. & + & & \\
\hline & Ergatettix sp. & + & & \\
\hline & Euparatettix variabilis & + & + & \\
\hline & Hedotettix gracilis & + & & \\
\hline \multicolumn{5}{|l|}{ Trigonopterygidae } \\
\hline Trigonopteryginae & Systella rafflesii & + & & + \\
\hline \multicolumn{5}{|l|}{ Suborder Ensifera } \\
\hline \multicolumn{5}{|l|}{ Gryllacrididae } \\
\hline Gryllacridinae & Gryllacris sp. & & & + \\
\hline \multicolumn{5}{|l|}{ Gryllidae } \\
\hline Eneopterinae & Nisitrus vittatus & & & + \\
\hline \multirow[t]{2}{*}{ Gryllinae } & Gymnogryllus sylvestris & & + & + \\
\hline & Velarifictorus aspersus & & + & + \\
\hline Itarinae & Itara johni & & & + \\
\hline Landrevinae & Endodrelanva jimini & & & + \\
\hline \multirow{2}{*}{ Phaloriinae } & Phaloria jerelynae & & & + \\
\hline & Tremellia timah & & & + \\
\hline \multirow[t]{4}{*}{ Podoscirtinae } & Aphonoides sp. & & + & + \\
\hline & $\begin{array}{l}\text { Mnesibulus (Mnesibulus) cf. } \\
\text { brunnerianus }\end{array}$ & & + & + \\
\hline & Sonotrella (Calyptotrella) bipunctata & & + & + \\
\hline & Varitrella (Cantotrella) orion & & & + \\
\hline Pteroplistinae & Singapuriola separata (Fig. 1C) & & & + \\
\hline \multicolumn{5}{|l|}{ Trigonidiidae } \\
\hline \multirow[t]{4}{*}{ Trigonidiinae } & Amusurgus sp. 1 & & & + \\
\hline & Amusurgus sp. 2 & & & + \\
\hline & Amusurgus sp. 3 & & & + \\
\hline & Anaxipha (probably Svistella) sp. & & & + \\
\hline \multicolumn{5}{|l|}{ Gryllotalpidae } \\
\hline \multirow[t]{3}{*}{ Gryllotalpinae } & Gryllotalpa c.f. nymphicus & & & + \\
\hline & Gryllotalpa fulvipes & & & + \\
\hline & Gryllotalpa wallace & & & + \\
\hline
\end{tabular}


Table 1. Continuation.

\begin{tabular}{|c|c|c|c|c|}
\hline Family (Subfamily) & Taxon & 1960 s to $1970 \mathrm{~s}$ & $1980 \mathrm{~s}$ & 2010s \\
\hline \multicolumn{5}{|l|}{ Mogoplistidae } \\
\hline \multirow[t]{5}{*}{ Mogoplistinae } & Cycloptiloides c.f. timah & & & + \\
\hline & Micrornebius kopisua & & & + \\
\hline & Ornebius albipalpus & & & + \\
\hline & Ornebius c.f. pullus (Fig. 1D) & & & + \\
\hline & Ornebius insculpta & & & + \\
\hline \multicolumn{5}{|l|}{ Tettigoniidae } \\
\hline \multirow[t]{4}{*}{ Conocephalinae } & Euconocephalus sp. & & + & \\
\hline & Nahlaksia bidadari & & & + \\
\hline & Oxylakis singaporensis & & & + \\
\hline & Peracca macritchiensis & & & + \\
\hline \multirow[t]{6}{*}{ Meconematinae } & Alloteratura sp. & & & + \\
\hline & Asiophlugis temasek (Fig. 1E) & + & + & + \\
\hline & Asiophlugis thaumasia & & & + \\
\hline & Carliphisis sp. & & & + \\
\hline & Neophisis (Indophisis) siamensis & & & + \\
\hline & Xiphidiopsis sp. & & & + \\
\hline Mecopodinae & Mecopoda elongata & & + & \\
\hline \multirow[t]{15}{*}{ Phaneropterinae } & Arnobia pilipes tropica $($ Fig. 1F) & & + & \\
\hline & Casigneta c.f. bisinuata & & + & \\
\hline & Cesasundana lorniensis & + & & \\
\hline & Ducetia japonica & + & & \\
\hline & Elimaea (Elimaea) sp. & & + & + \\
\hline & Elimaea (Rhaebelimaea) signata & + & & \\
\hline & Holochlora sp. & & + & \\
\hline & Holochlora c.f. signata signata & + & & + \\
\hline & Holochlora paradoxa & + & & \\
\hline & Leptoderes ornatipennis & + & & \\
\hline & Macedna martini & + & & \\
\hline & Phygela haanii & & + & \\
\hline & Psyrana c.f. sondaica & & + & \\
\hline & Scambophyllum sanguinolentum & + & & \\
\hline & Sympaestria c.f. acutelobata & & + & \\
\hline \multirow[t]{2}{*}{ Pseudophyllinae } & Mioacris/Promeca sp. & & + & \\
\hline & Phyllomimus inversus & & & + \\
\hline
\end{tabular}




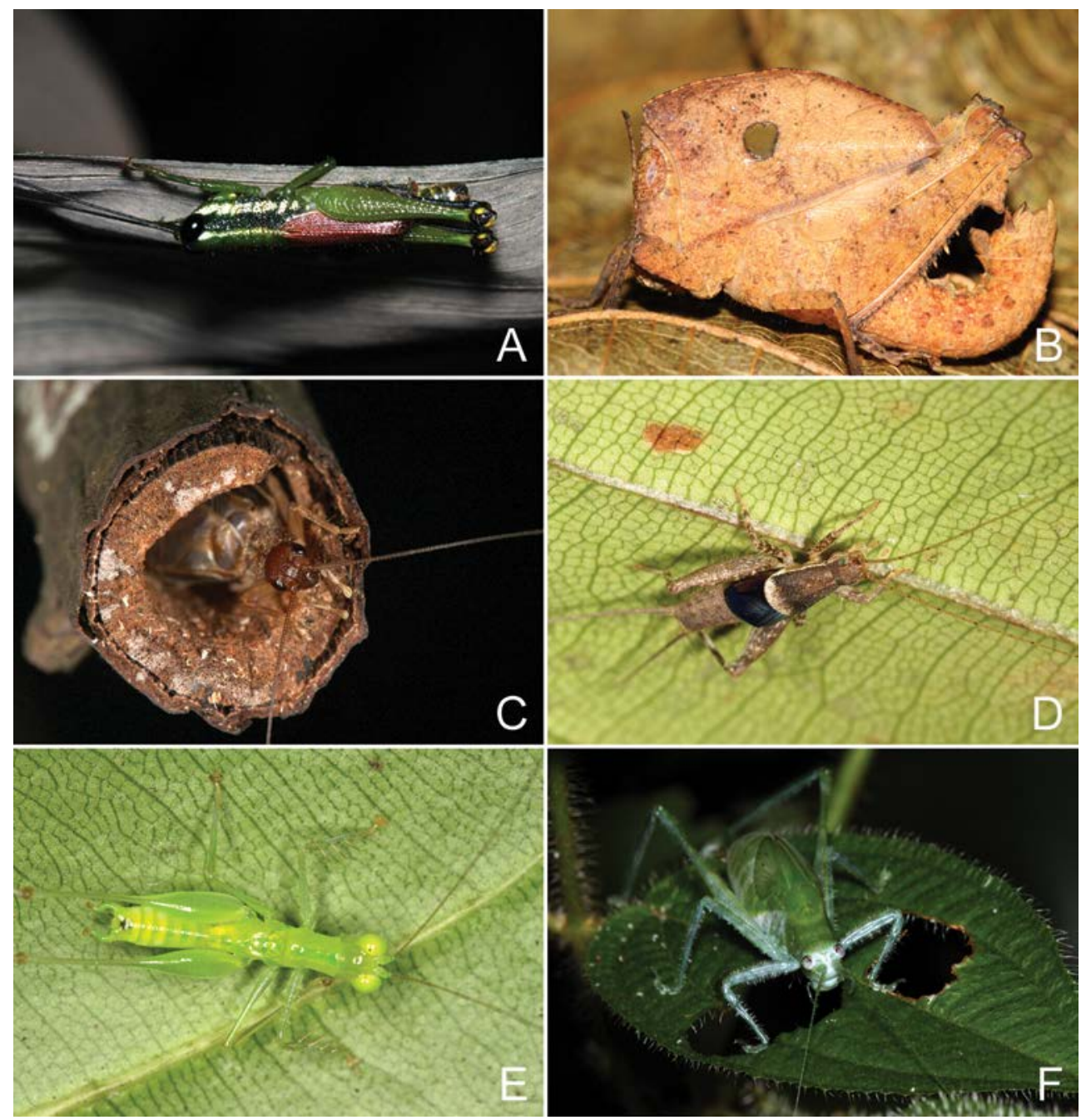

Fig 1. In-situ photographs of orthopterans recorded from BTNR. A. Lucretilis sp. B. Chorotypus biemarginatus. C. Singapuriola seperata. D. Ornebius c.f. pullus. E. Asiophlugis temasek. F. Arnobia pilipes tropica. (Photos: M.K. Tan)

been collected since first being recorded between the 1960s and 1980s (Table 1). The collections in the 1960s and 1970s included mainly Caelifera, with many species of Acrididae and Tetrigidae, and the relatively fewer Ensifera collected then were mostly members of the Tettigonidae (subfamily Phaneropterinae). The collections in the 1980s included some Caelifera in the family Acrididae, and some Ensifera in the Tettigonidae and Gryllidae. The collections in the 2010s included few Caelifera but many Ensifera in the families Gryllidae, Gryllotalpidae, Mogoplistidae and Tettigonidae (various subfamilies). While this may suggest new records or local extinctions, caution must be taken over such claims. These collections were typically 
opportunistic and no absence data was collected. Of the total 83 species, 67 were collected by only one of the three main collectors, and only one species, Asiophlugis temasek, was collected by all three, although that species happens to have been unnamed until very recently (Gorochov \& Tan, 2011). In the case of the collection in the early 2010s, the objective was to collect as many species as possible from BTNR and CCNR. More surveys conducted at night could account for a much larger proportion of nocturnal Ensifera located by their stridulations. Only a few specimens for each species were collected, as compared to more indiscriminate collecting in the 1960s and 1970s. Hence, this checklist should only be used as a baseline, and inferences on extinctions, population, rarity or abundance, and distribution should be made with caution.

While the diversity of orthopterans in Singapore is well-studied and the taxonomy of many species is well resolved, little is known about their ecology and natural history. This is especially the case because little attention has been paid to this group of insects until now. Recently, documentation of orthopterans as important prey to charismatic mammals (including common palm civets and leopard cats) (Chua et al., 2016; Fung et al., 2018), as well as potentially being important flower-visitors and/ or pollinators (Tan et al., 2017b; Tan \& Tan, 2018), sheds some light on their ecology in Singapore and Southeast Asia. None of this recent work was done in BTNR, indicating that the ecology and natural history of orthopterans in BTNR is inadequately studied. If orthopterans are to be useful indicators or model organisms for conservation management of BTNR, more studies and interest would be helpful. Therefore, the objective of this checklist is to provide baseline information to facilitate future research on the orthopterans and insects of BTNR.

ACKNOWLEDGEMENTS. The author thanks curators of LKCNHM for access to the ZRC. The work was supported by the Lady Yuen Peng McNeice Graduate Fellowship of the National University of Singapore.

\section{References}

Chan, L. \& Davison, G.W.H. (2019). Introduction to the Comprehensive Biodiversity Survey of Bukit Timah Nature Reserve, Singapore, 2014-2018. Gard. Bull. Singapore 71 (Suppl. 1): 3-17.

Chua, M.A., Sivasothi, N. \& Meier, R. (2016). Population density, spatiotemporal use and diet of the leopard cat (Prionailurus bengalensis) in a human-modified succession forest landscape of Singapore. Mamm. Res. 61: 99-108.

Cigliano, M.M., Braun, H., Eades, D.C. \& Otte, D. (2018). Orthoptera Species File, version 5 (5.0). http://Orthoptera.SpeciesFile.org

Fung, T.K., Tan, M.K. \& Sivasothi, N. (2018). Orthoptera in the scat content of the common palm civet (Paradoxurus hermaphroditus) in Pulau Ubin, Singapore. Nat. Singapore 11: $37-44$. 
Gorochov, A.V. \& Tan, M.K. (2011). New katydids of the genus Asiophlugis Gor. (Orthoptera: Tettigoniidae: Meconematinae) from Singapore and Malaysia. Russian Entomol. J. 20(2): 129-133.

Song, H., Amédégnato, C., Cigliano, M.M., Desutter-Grandcolas, L., Heads, S.W., Huang, Y., Otte, D. \& Whiting, M.F. (2015). 300 million years of diversification: elucidating the patterns of orthopteran evolution based on comprehensive taxon and gene sampling. Cladistics 31(6): 621-651.

Tan, M.K. (2010). Orthoptera of the vacant lots in Bedok South. Nat. Singapore 3: 69-81.

Tan, M.K. (2011). The Copiphorini (Orthoptera: Tettigoniidae: Conocephalinae) in Singapore. Nat. Singapore 4: 31-42.

Tan, M.K. (2012a). Orthoptera in the Bukit Timah and Central Catchment Nature Reserves (Part 1): Suborder Caelifera. Singapore: Raffles Museum of Biodiversity Research, National University of Singapore.

Tan, M.K. (2012b). Orthoptera in the Bukit Timah and Central Catchment Nature Reserves (Part 2): Suborder Ensifera. Singapore: Raffles Museum of Biodiversity Research, National University of Singapore.

Tan, M.K. (2014). An annotated checklist of the bush katydids (Orthoptera: Phaneropteridae: Phaneropterinae) from Singapore, including an illustrated key to species. Zootaxa 3884(6): 573-593.

Tan, M.K. (2017). Orthoptera in the Bukit Timah and Central Catchment Nature Reserves (Part 2): Suborder Ensifera, $2^{\text {nd }}$ ed. Singapore: Lee Kong Chian Natural History Museum, National University of Singapore.

Tan, M.K. \& Tan, H.T.W. (2018). A gentle floriphilic katydid Phaneroptera brevis can help with pollination of Bidens pilosa. Ecology 99: 2125 - 2127.

Tan, M.K. \& Wang, L.K. (2012). The Orthoptera of Semakau Landfill, Singapore: A Project Semakau checklist. Nat. Singapore 5: 309-318.

Tan, M.K., Ngiam, R.W.J. \& Ismail, M.R.B. (2012). A checklist of Orthoptera in Singapore parks. Nat. Singapore 5: 61-67.

Tan, M.K., Yeo, H. \& Hwang, W.S. (2017a). Ground dwelling pygmy grasshoppers (Orthoptera: Tetrigidae) in Southeast Asia tropical freshwater swamp forest prefer wet microhabitats. J. Orthoptera Res. 26(1): 73-80.

Tan, M.K., Artchawakom, T., Wahab, R.A., Lee, C.-Y., Belabut, D.M. \& Tan, H.T.W. (2017b). Overlooked flower visiting Orthoptera in Southeast Asia. J. Orthoptera Res. 26(2): 143-153.

Tan, M.K., Choi, J. \& Shankar, N. (2017c). Trends in new species discovery of Orthoptera (Insecta) from Southeast Asia. Zootaxa 4238(1): 127-134.

Willemse, L. (2001). Fauna Malesiana, Guide to the Pest Orthoptera of the Indo-Malayan Region. Leiden, Netherlands: Backhuys. 